\title{
Ionic Liquid-Based Dispersive Liquid-Liquid Microextraction for the Simultaneous Determination of Carbamazepine and Lamotrigine in Biological Samples
}

\author{
Salumeh Ranjbar, Ameneh Porgham Daryasari ${ }^{*}$ and Mojtaba Soleimani \\ Department of Chemistry, Lahijan Branch, Islamic Azad University, Lahijan, Iran P.O.Box 4416939515 \\ * Corresponding author: E-mail: porgham54@gmail.com \\ Tel.: +981342230561; Fax: +981342224756
}

Received: 11-07-2019

\begin{abstract}
This paper describes a new approach for the determination of carbamazepine and lamotrigine in biological samples by ionic liquid dispersive liquid-phase microextraction prior to high-performance liquid chromatography with ultraviolet detection. The effects of different ionic liquids (ILs) on the extraction efficiency of carbamazepine and lamotrigine were investigated. The highest extraction efficiencies of carbamazepine and lamotrigine were obtained using $30 \mu \mathrm{L}$ of 1 -methyl-3-octylimidazolium hexafluorophosphate [C8MIM][PF6]. Several factors affecting the microextraction efficiency, such as the type and volume of extracting solvent, type and volume of disperser solvent, salt concentration, and $\mathrm{pH}$ of the sample solution have been optimized. The calibration plots were linear in the range of $0.1-20 \mathrm{mg} \mathrm{L}^{-1}$ for carbamazepine and $0.3-40 \mathrm{mg} \mathrm{L}^{-1}$ for lamotrigine with detection limits of $0.04 \mathrm{mg} \mathrm{L}^{-1}$ for carbamazepine and $0.07 \mathrm{mg} \mathrm{L}^{-1}$ for lamotrigine in plasma samples. The results confirm the suitability of the presented method as a sensitive method for the analysis of the target analytes in urine and plasma samples.
\end{abstract}

Keywords: Ionic liquids; dispersive liquid-liquid microextraction; carbamazepine; lamotrigine; human urine; human plasma

\section{Introduction}

One of the most common serious neurological disorders is epilepsy. ${ }^{1}$ Anti-epileptic drugs (AEDs) are the main form of treatment for epilepsy. Carbamazepine and newer AEDs like lamotrigine (LTG) are among the firstline medicines for treatment of seizures. ${ }^{2}$ Lamotrigine (LTG), chemically known as [6-(2,3-dichlorophenyl) -1,2,4-triazine-3,5-diamine], is used as monotherapy and as an adjunct with other antiepileptics for treatment of<smiles>NC(=O)N1c2ccccc2C=Cc2ccccc21</smiles>

Carbamazepine<smiles>Nc1nnc(-c2cccc(Cl)c2Cl)c(N)n1</smiles>

Lamotrigine
Figure 1. The structure of carbamazepine and lamotrigine partial and generalized toxic-clonic seizures. It's used as a tranquilizer and in the treatment of neurological lesions. ${ }^{3,4}$

Carbamazepine (CBZ) (5-H-dibenzo[b,f]azepine-5 -carboxamide), is a first line antiepileptic drug used in the treatment of partial and generalized tonic-clonic seizures. ${ }^{5}$ The chemical structures of carbamazepine and lamotrigine are shown in Figure 1.

Most biological samples have complex matrices and the analytes are typically present at low concentration levels, which are not detectable by the analytical instrument. Therefore, a sample preparation step is generally required to extract, isolate, and concentrate the analytes of interest.

Different analytical techniques that have been used for the determination of lamotrigine include planar chromatography, ${ }^{6}$ HPLC, ${ }^{7}$ TLC and HPLC, ${ }^{8}$ GC, ${ }^{9}$ HPLC and GC, ${ }^{10}$ capillary electrophoresis, ${ }^{11}$ and immunoassay. ${ }^{12}$ High performance liquid chromatography (HPLC-UV, HPLC-DAD) and immunoassay were used for determination of carbamazepine in biological materials. Also, gas chromatography with mass spectrometry and liquid chromatography with mass spectrometry have been reported. ${ }^{13-15}$ 
Liquid-liquid extraction (LLE), ${ }^{16}$ solid-phase extraction (SPE), ${ }^{17}$ and stir bar-sorptive extraction (SBSE) ${ }^{18}$ have been developed for the determination of CBZ in biological fluids. These methods are time consuming and require substantial amounts of toxic organic solvents. The sample preparation methods employed for lamotrigine involve SPME, ${ }^{19} \mathrm{SPE},{ }^{20}$ protein precipitation (PP), ${ }^{21} \mathrm{LLE},{ }^{22}$ and microextraction by packed sorbent (MEPS). ${ }^{23}$

A novel microextraction method called dispersive liquid-liquid microextraction (DLLME) was introduced in 2006. ${ }^{24}$ DLLME utilizes an extraction solvent and a dispersive solvent to produce a cloudy solution. DLLME has become a very popular technique for the extraction of different compounds. ${ }^{25-27}$ Generally, the extraction solvent used in DLLME is highly toxic and not environmentally friendly.

In environmentally friendly sample preparation methods, it is important to use liquid solvents in reduced amounts, replaced with green solvents or even completely eliminated from the analytical procedure. ${ }^{28}$ Ionic liquids (ILs) are considered to be "environmentally friendly solvents" ${ }^{29}$ The immiscibility of ILs in water and their capability to solubilize organic species has made them suitable to extract the compounds. ${ }^{30}$ Recently, ionic liquid DLLME is very popular. ${ }^{31}$

In this paper, for the first time, DLLME method using IL as extraction solvent combined with high-performance liquid chromatography has been developed for the simultaneous determination of carbamazepine and lamotrigine in biological samples. The parameters affecting the extraction efficiency, such as the type and volume of extracting solvent, type and volume of disperser solvent, salt concentration, and $\mathrm{pH}$ of the sample solution have been optimized. The proposed method was successfully applied to determine carbamazepine and lamotrigine in biological samples.

\section{Experimental}

\section{1. Chemicals and Reagents}

Carbamazepine and lamotrigine were obtained from Sobhan Darou Company (Rasht, Iran). Acetone, acetonitrile, methanol, and sodium chloride were obtained from Merck Company (Germany). Ionic liquids (ILs) [C8MIM] [PF6] and [C6MIM][PF6] were obtained from SIGMA-ALDRICH. IL [C4MIM][PF6] was obtained from Fluka. Buffer solution (disodium hydrogen phosphate potassium dihydrogen phosphate, $\mathrm{pH}=6.88$ ) was obtained from Merck. Sodium dihydrogen phosphate, disodium hydrogen phosphate, sodium hydrogen carbonate, and disodium carbonate were obtained from Merck. Deionized water was used in all experiments. Stock standard solutions of the analytes were prepared by dissolution of each drug in methanol, having a concentration of $1000 \mathrm{mg}$ $\mathrm{L}^{-1}$. Fresh standard solutions were prepared by diluting the standard solution of the analytes with deionized water of required concentration. All these solutions were stored at $4{ }^{\circ} \mathrm{C}$ in the absence of light.

\section{2. Apparatus}

Chromatographic analysis was performed using a Shimadzu (LC-20AD prominence, Japan) with a photodiode array detector (SPD-M20A). Separations were carried out on a $\mu$ Boundapak C18 column of $15 \mathrm{~cm} \times 4.6 \mathrm{~mm}$ with $5 \mu \mathrm{m}$ particles. HPLC data were acquired and processed using a Lab solution software (LC solution version 1.25 SP5). The mobile phase was phosphate buffer ( $\mathrm{pH}$ 6.8) methanol - acetonitrile (70:20:10, $v / v / v)$ at a flow rate of $1.0 \mathrm{~mL} \mathrm{~min}{ }^{-1}$ under isocratic conditions. The detection was performed at the wavelength of 284 and $308 \mathrm{~nm}$ for carbamazepine and lamotrigine, respectively. In the measurement of lamotrigine (LTG) and carbamazepine (CBZ) in the optimization steps and also determination in real samples, the mixture of both drugs were used. The maximum wavelengths for measurement of LTG and CBZ were $308 \mathrm{~nm}$ and $284 \mathrm{~nm}$, respectively. Unfortunately, in 308 $\mathrm{nm}$ and $284 \mathrm{~nm}$, both of the drugs have peaks. However, $\mathrm{CBZ}$ at $284 \mathrm{~nm}$ and LTG at $308 \mathrm{~nm}$ have peaks with high intensities. The maximum intensity of the peaks of each drug at the selected wavelengths were used for the subsequent experiments. A centrifuge model ALC 4232 was used to perform the centrifuge process (USA). The $\mathrm{pH}$ meter model 827 Metrohm (Herisau, Switzerland) was used for $\mathrm{pH}$ measurements.

\section{3. Dispersive Liquid-liquid Microextraction procedure}

Five milliliters of sample solution containing the analytes was poured into a centrifuge glass vial. The $\mathrm{pH}$ of the solution was adjusted to 10 by using sodium bicarbonate. A mixture containing $30 \mu \mathrm{L}$ of [C8MIM][PF6] (as extraction solvent) and $100 \mu \mathrm{L}$ of methanol (as disperser solvent) was injected into the sample solution. Cloudy solution was formed as the fine droplets of the immiscible extraction solvent dispersed in the sample. This process enlarged the contact area between the extraction solvent and sample, and the analytes were extracted into the formed fine droplets. Then it was placed in ice bath for 2 $\mathrm{min}$. The cloudy solution was centrifuged at $3500 \mathrm{rpm}$ for $10 \mathrm{~min}$ to separate the phases. Finally, $100 \mu \mathrm{L}$ methanol was added into the collected IL and injected into the HPLC system.

\section{Results and Discussion}

In the present study, the applicability of ionic liquid DLLME combined with HPLC was considered for the simultaneous determination of carbamazepine and lamo- 
trigine in biological samples. There are several factors which affect the extraction process including type and volume of extracting solvent, type and volume of disperser solvent, salt concentration and $\mathrm{pH}$ of the sample solution. Optimization of the variables was performed using one variable at a time method. All experiments were replicated three times. The spiked concentration level in the optimization study was $5 \mathrm{mg} \mathrm{L}^{-1}$ of carbamazepine and $20 \mathrm{mg} \mathrm{L}^{-1}$ of lamotrigine. Enrichment factor (EF) and extraction recovery (ER) were calculated based on the following equations:

$$
\begin{aligned}
& \mathrm{EF}=\mathrm{C}_{\text {sedimented }} / \mathrm{C}_{0} \\
& E R(\%)=\frac{C_{\text {sedimented }} \times V_{\text {sedimented }}}{C_{0} \times V_{\text {sample }}} \times 100= \\
& =E F \times \frac{V_{\text {sedimented }}}{V_{\text {sample }}} \times 100
\end{aligned}
$$

Where, $\mathrm{EF}, \mathrm{C}_{\text {sedimented }}$ and $\mathrm{C}_{0}$ are the enrichment factor, concentration of the analyte in the sedimented phase, and initial concentration of the analyte in the sample, respectively. ER\%, $V_{\text {sedimented }}$ and $V_{\text {sample }}$ are the extraction recovery, volume of the sedimented phase, and volume of the sample, respectively. $\mathrm{C}_{\text {sedimented }}$ is calculated from a suitable direct injection calibration curve. Blank urine and plasma was obtained from ten different healthy volunteers. Different sources of blank urine and plasma $(n=3)$ were used for testing the endogenous interferences. There were no interfering peaks at either the carbamazepine or lamotrigine retention time.

\section{1. Effect of $\mathbf{p H}$}

The sample $\mathrm{pH}$ is an important factor in the enrichment process and can affect the extraction efficiencies of the analytes. In this study, the $\mathrm{pH}$ values of the sample solutions were adjusted between 7 and 11 with buffers of

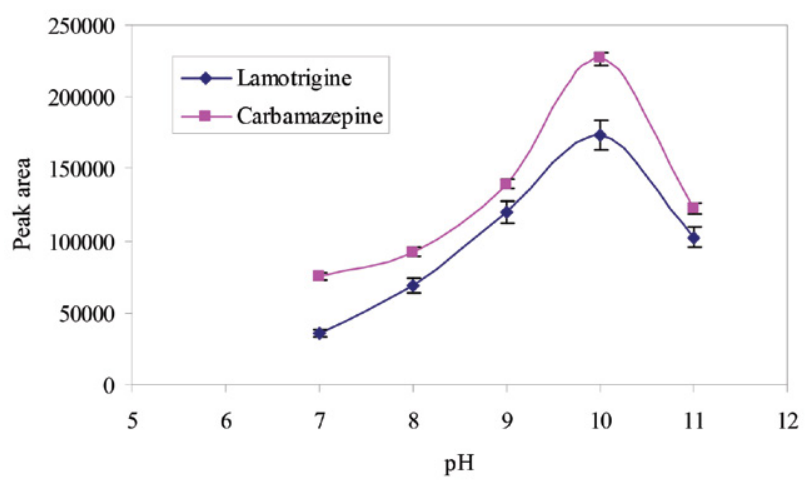

Figure 2. Effect of $\mathrm{pH}$ on the extraction efficiency, Extraction conditions: extraction solvent: [C4MIM][PF6], extraction solvent volume: $30 \mu \mathrm{L}$; dispersive solvent: methanol; dispersive solvent volume: $100 \mu \mathrm{L}$; concentration of $\mathrm{NaCl}(w / v): 1.0 \%$ sodium phosphate and sodium bicarbonate. As seen in Figure 2, the best peak areas were obtained at $\mathrm{pH} 10$. The $\mathrm{p} K_{\mathrm{a}}$ value for CBZ is 13.13 and the $\mathrm{p} K_{\mathrm{a}}$ value for LTG is 5.3. At the $\mathrm{pH} 10$, the analytes were extracted based on hydrophobic interaction. Also, in acidic $\mathrm{pH}$, the drugs were decomposed. Thus, $\mathrm{pH} 10$ was selected as the optimum value.

\section{2. Selection of Extraction Solvent}

In the selection of the extraction solvent, certain properties of the IL that need to be considered are: (1) to extract carbamazepine and lamotrigine well; (2) to have higher density than water; and (3) to form a cloudy solution in the presence of dispersive solvent. In this study, three ionic liquids, including [C8MIM][PF6], [C6MIM] $[\mathrm{PF} 6]$, and $[\mathrm{C} 4 \mathrm{MIM}][\mathrm{PF} 6]$ were investigated. By comparing them as extraction solvents, it was observed that carbamazepine and lamotrigine exhibited a better affinity for [C8MIM][PF6], because of higher solubility of the mentioned drugs in [C8MIM][PF6] (Figure 3). Therefore, [C8MIM][PF6] was selected as extraction solvent in the subsequent experiments.

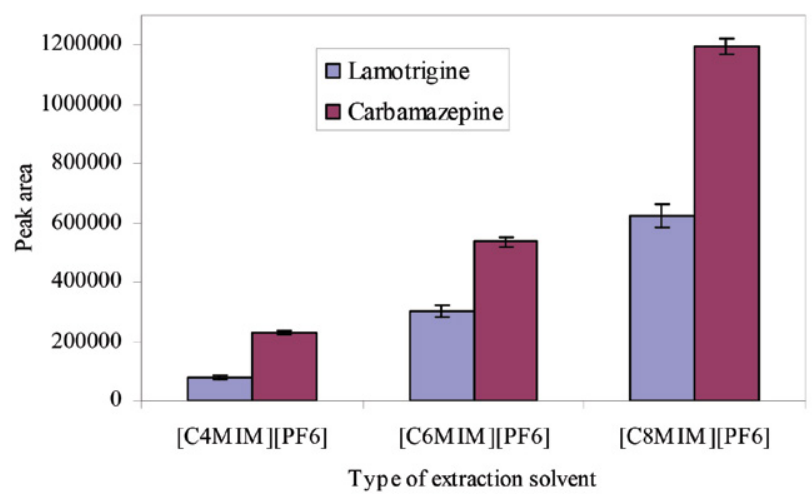

Figure 3. Effect of type of extraction solvent on the extraction efficiency, Extraction conditions: extraction solvent volume: $30 \mu \mathrm{L}$; dispersive solvent: methanol; dispersive solvent volume: $100 \mu \mathrm{L}$; concentration of $\mathrm{NaCl}(w / v): 1.0 \%, \mathrm{pH}: 10$

\section{3. Effect of Extraction Solvent Volume}

Optimization of the volume of the IL as an extraction solvent is a further step in the development of a IL-DLLME procedure. The volume of the extraction solvent can influence formation of dispersion and thus has to be optimized. In order to study the effect of extraction solvent volume, different volumes of [C8MIM][PF6] $(20-50 \mu \mathrm{L}$ in $10 \mu \mathrm{L}$ intervals) were tested. It was observed (Figure 4) that the peak areas were increased by increasing the [C8MIM] [PF6] volume up to $30 \mu \mathrm{L}$ for carbamazepine and lamotrigine. The peak areas of the analytes decreased by increasing the volume of [C8MIM][PF6], which was an expected result due to dilution of the extracted analytes in the extraction solvent at higher volumes. Therefore, $30 \mu \mathrm{L}$ of [C8MIM] [PF6] was selected as the optimum volume. 


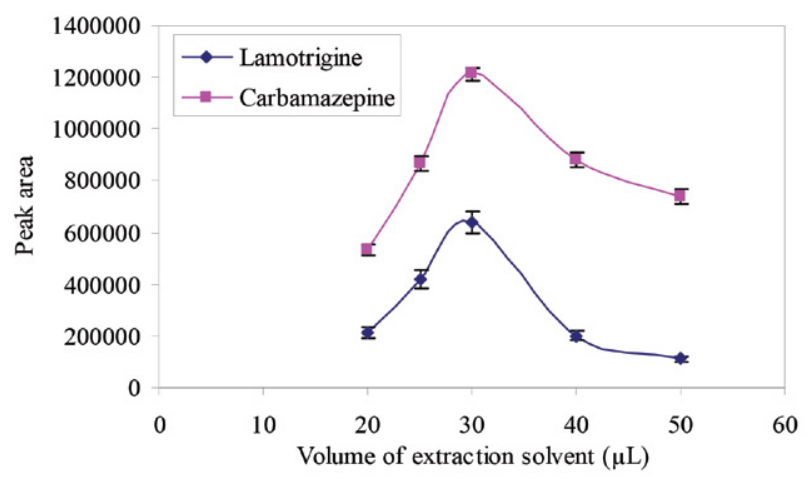

Figure 4. Effect of volume of extraction solvent on the extraction efficiency, Extraction conditions: extraction solvent: [C8MIM] [PF6], dispersive solvent: methanol; dispersive solvent volume: 100 $\mu \mathrm{L}$; concentration of $\mathrm{NaCl}(w / v): 1.0 \%, \mathrm{pH}: 10$

\section{4. Effect of Type of Disperser Solvent}

In the IL-DLLME, the disperser solvent should be soluble in the extraction solvent and miscible in the sample solution, thus enabling the formation of fine droplets of the extraction solvent. Therefore, acetonitrile, methanol, and acetone were tested as dispersive solvents. A series of sample solutions were examined using $100 \mu \mathrm{L}$ of each of the disperser solvents containing $30 \mu \mathrm{L}$ of [C8MIM] [PF6]. By using acetone and acetonitrile, the cloudy solution was not formed well. It was clear that (Figure 5) the best peak areas were obtained when methanol was used as a disperser solvent. Hence, the subsequent experiments were performed using methanol as the disperser solvent.

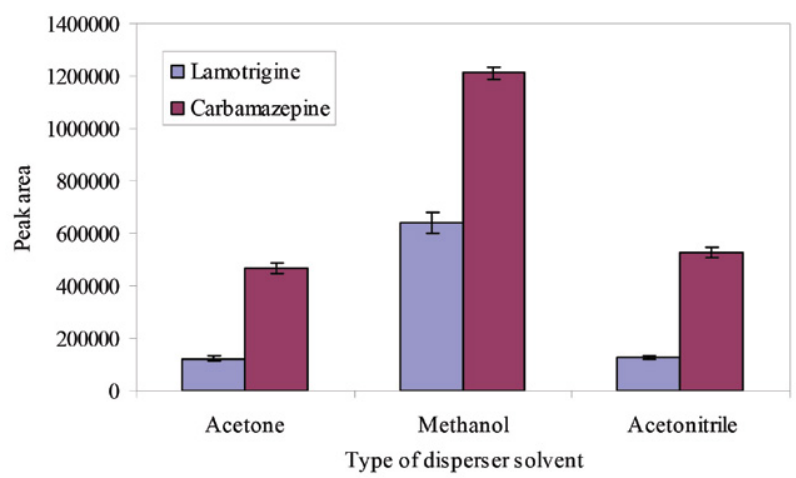

Figure 5. Effect of type of disperser solvent on the extraction efficiency, Extraction conditions: extraction solvent: [C8MIM][PF6], extraction solvent volume: $30 \mu \mathrm{L}$; dispersive solvent volume: $100 \mu \mathrm{L}$; concentration of $\mathrm{NaCl}(w / v): 1.0 \%, \mathrm{pH}: 10$

\section{5. Effect of Volume of Disperser Solvent}

In order to study the effect of disperser solvent volume, different volumes of methanol $(50,100,300,500$, and $1000 \mu \mathrm{L}$ ) were used. It is clear from Figure 6 that 100 $\mu \mathrm{L}$ methanol gave the highest peak areas. It seems that at the volume of $100 \mu \mathrm{L}$, the amount of methanol was enough for effective forming of the cloudy solution. At lower volume of methanol, cloudy solution was not properly formed resulting in a decrease in the peak areas. At higher volume of methanol, the solubility of the analytes in the sample increased resulting in a decrease in the peak areas. Thus, $100 \mu \mathrm{L}$ was selected as the optimum volume of methanol.

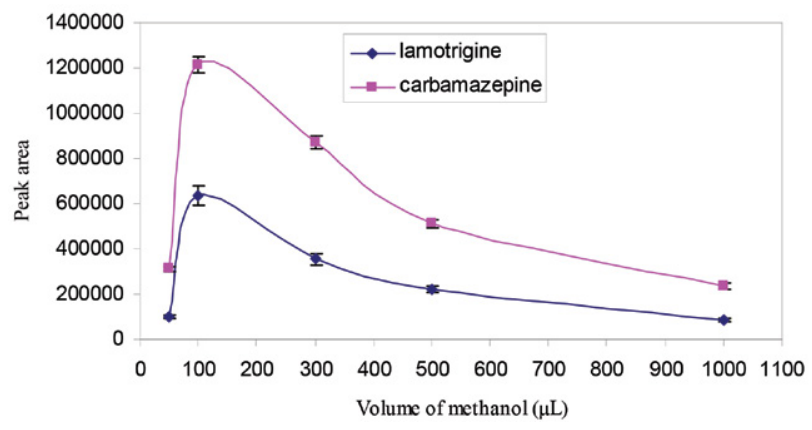

Figure 6. Effect of volume of methanol on the extraction efficiency, Extraction conditions: extraction solvent: [C8MIM][PF6], extraction solvent volume: $30 \mu \mathrm{L}$; dispersive solvent: methanol; concentration of $\mathrm{NaCl}(w / v): 1 \%$; $\mathrm{pH}: 10$

\section{6. Salt Addition}

Generally, salt addition can cause a decrease in the solubility of the analytes in sample solution and enhance extraction efficiency. To evaluate the possibility of salting-out effect, the extraction efficiency was studied with the sodium chloride ranging from 0.5 to $1.5 \%(w / v)$ (Figure 7). Due to the salting-out effect, the peak areas increased as the amount of $\mathrm{NaCl}$ increased from 0.5 to $1.0 \%(w / v)$. By increasing the ionic strength $(\mathrm{NaCl}$ concentration from 1.0 to $1.5 \%(w / v)$ ), a reduction of the peak areas for carbamazepine and lamotrigine were observed because of dilution effect. Based on the results, $1.0 \%(w / v)$ of $\mathrm{NaCl}$ was added in all the subsequent experiments.

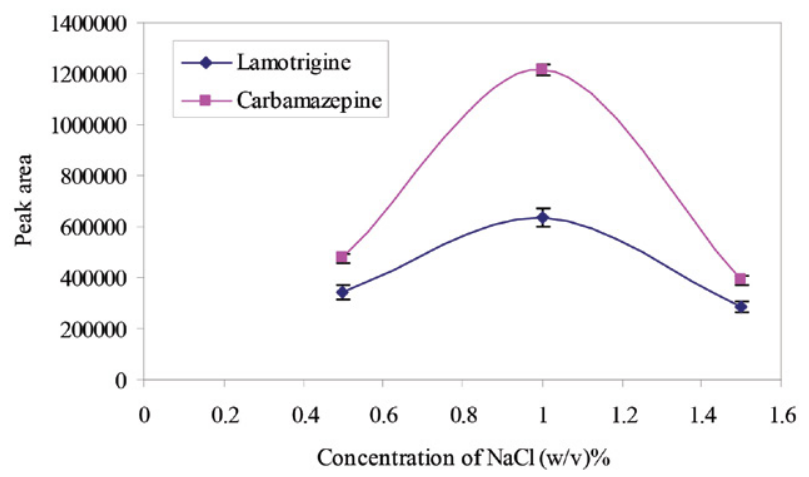

Figure 7. Effect of $\mathrm{NaCl}$ concentration on the extraction efficiency, Extraction conditions: extraction solvent: [C8MIM][PF6], extraction solvent volume: $30 \mu \mathrm{L}$; dispersive solvent: methanol; dispersive solvent volume: $100 \mu \mathrm{L} ; \mathrm{pH}: 10$ 


\section{7. Analytical Performance and Method Validation}

Calibration data of carbamazepine and lamotrigine were obtained using IL-DLLME-HPLC system under optimum conditions. For urine samples, the linearity of calibration curve was observed in the range of $0.07-20 \mathrm{mg} \mathrm{L}^{-1}$ for carbamazepine and $0.17-40 \mathrm{mg} \mathrm{L}^{-1}$ for lamotrigine. The coefficients of determination $\left(R^{2}\right)$ were 0.991 and 0.997 for carbamazepine and lamotrigine, respectively. The limits of detection (LODs) based on signal-to-noise ratio $(\mathrm{S} / \mathrm{N})$ of 3 , were 0.02 and $0.05 \mathrm{mg} \mathrm{L}^{-1}$ for carbamazepine and lamotrigine, respectively. The limits of quantification (LOQs), based on signal-to-noise ratio $(\mathrm{S} / \mathrm{N})$ of 10 , were 0.07 and $0.17 \mathrm{mg}$ $\mathrm{L}^{-1}$ for carbamazepine and lamotrigine, respectively. The relative standard deviation (RSD\%, $n=5$ ) at the concentration level of $5.0 \mathrm{mg} \mathrm{L}^{-1}$ of carbamazepine and lamotrigine were $1.7 \%$ and $5.6 \%$ for carbamazepine and lamotrigine, respectively. Enrichment factors were 35 and 26 for carbamazepine and lamotrigine, respectively. Extraction recoveries were 70 and $52 \%$ for carbamazepine and lamotrigine, respectively. However, for plasma samples, linearity was observed in the range of $0.1-20 \mathrm{mg} \mathrm{L}^{-1}$ for carbamazepine and $0.3-40 \mathrm{mg} \mathrm{L}^{-1}$ for lamotrigine. The $R^{2}$ were 0.987 and 0.995 for carbamazepine and lamotrigine, respectively. The limits of detection (LODs) based on signal-to-noise ratio $(\mathrm{S} / \mathrm{N})$ of 3 , were 0.04 and $0.07 \mathrm{mg} \mathrm{L}^{-1}$ for carbamazepine and lamotrigine, respectively. The limits of quantification
(LOQs), based on signal-to-noise ratio $(\mathrm{S} / \mathrm{N})$ of 10 , were 0.1 and $0.3 \mathrm{mg} \mathrm{L}^{-1}$ for carbamazepine and lamotrigine, respectively. The relative standard deviation $(\mathrm{RSD} \%, n=5)$ at the concentration level of $5.0 \mathrm{mg} \mathrm{L}^{-1}$ of carbamazepine and lamotrigine were $3.2 \%$ and $8.4 \%$ for carbamazepine and lamotrigine, respectively. Enrichment factors were 27 and 19 for carbamazepine and lamotrigine, respectively. Extraction recoveries were 54 and $38 \%$ for carbamazepine and lamotrigine, respectively.

The selectivity of the method was evaluated by analysing six blank plasma and urine samples to evaluate the existence of matrix endogenous substances at retention times that could interfere with carbamazepine (CBZ) and lamotrigine (LTG) peaks. The analysis of blank human plasma and urine samples from six healthy volunteers confirmed the absence of endogenous interferences at the retention times of carbamazepine and lamotrigine.

The stability of CBZ and LTG stock solutions were evaluated at room temperature for $8 \mathrm{~h}$ and $24 \mathrm{~h}$ and after storage at $-20{ }^{\circ} \mathrm{C}$ for 10 days. Stability was calculated by comparing the pertinent responses obtained from the tested stock solution(s) with the responses of freshly prepared ones and the results are given in Table 1. According to the results obtained, CBZ and LTG was stable in human plas$\mathrm{ma}$ and urine samples in the different storage conditions.

Absolute recoveries of the analytes were determined in triplicates at high, medium and low concentrations in plasma and urine by extracting drug-free plasma and

Table 1. Summary of stability of CBZ and LTG in stock solution and human plasma and human urine

\begin{tabular}{|c|c|c|c|}
\hline \multicolumn{4}{|c|}{ Data on Stock Solution Stability } \\
\hline $\operatorname{Drug}(n=5)$ & $8 \mathrm{~h}$ at $\mathrm{RT}$ & $24 \mathrm{~h}$ at $\mathrm{RT}$ & 10 days at $-20^{\circ} \mathrm{C}$ \\
\hline \multicolumn{4}{|l|}{ CBZ } \\
\hline Precision (\%) & 1.2 & 1.8 & 1.5 \\
\hline Accuracy (\%) & 100.1 & 99.8 & 98.7 \\
\hline \multicolumn{4}{|l|}{ LTG } \\
\hline Precision (\%) & 3.5 & 3.7 & 3.0 \\
\hline Accuracy (\%) & 99.6 & 99.3 & 98.9 \\
\hline \multicolumn{4}{|c|}{ Data on Stability in Plasma Samples } \\
\hline \multicolumn{4}{|l|}{ CBZ } \\
\hline Precision (\%) & 3.0 & 3.3 & 3.6 \\
\hline Accuracy (\%) & 98.1 & 97.9 & 97.2 \\
\hline \multicolumn{4}{|l|}{ LTG } \\
\hline Precision (\%) & 7.8 & 8.0 & 7.6 \\
\hline Accuracy (\%) & 98.3 & 97.8 & 98.1 \\
\hline \multicolumn{4}{|c|}{ Data on Stability in Urine Samples } \\
\hline \multicolumn{4}{|l|}{$\mathrm{CBZ}$} \\
\hline Precision (\%) & 1.5 & 1.4 & 1.6 \\
\hline Accuracy (\%) & 98.8 & 99.1 & 97.8 \\
\hline \multicolumn{4}{|l|}{ LTG } \\
\hline Precision (\%) & 4.8 & 5.1 & 5.0 \\
\hline Accuracy (\%) & 98.2 & 98.5 & 97.8 \\
\hline
\end{tabular}


urine samples spiked with CBZ and LTG. Recovery was calculated by comparison of the analyte peak-areas of the extracted samples with those of the unextracted analyte standards, representing 94 and $88 \%$ recovery of CBZ and LTG, respectively, in plasma and 99 and $94 \%$ recovery of CBZ and LTG, respectively, in urine.

In order to evaluate the effect of matrix samples on the performance of the proposed method, determination of CBZ and LTG in human urine and plasma samples at the three different concentration levels were performed. For doing the IL-DLLME procedure on the plasma samples, some extra processes are needed. First the human plasmas were dissolved in a suitable amount of acetonitrile such as 1:1 $(v / v)$ reducing the matrix effect and then the mixtures were centrifuged. Secondly, they were filtered for getting a clear solution and removing the dirty solution at the bottom of test tubes. The samples was found to be free from the drugs. Therefore, specific amounts of CBZ and LTG at the three different concentration levels were spiked to the samples and analyzed by the proposed method. The spiking recoveries of the target compounds in the urine and plasma samples are summarized in Table 2. The relative recovery (RR) is obtained from the following equation:

$$
\mathrm{RR} \%=C_{\text {found }}-C_{\text {real }} / C_{\text {added }} \times 100
$$

where $C_{\text {found }}, C_{\text {real }}$, and $C_{\text {added }}$ are the concentrations of the analytes after the addition of a known amount of standard in a real sample, the concentration of the analytes in a real sample, and the concentration of a known amount of standard, which was spiked to the real sample, respectively. The relative recoveries were between $87-103 \%$ (Table 2) and showed that the matrix had negligible effect on the performance of the proposed method. The chromatograms of the urine and plasma sample (without spiking and spiked) are shown in Figures 8 and 9, respectively.

Table 3 compares the proposed method with the other extraction methods for the determination of the target analytes in biological samples. The comparison of extraction time of the proposed method with solid-phase microextraction (SPME) ${ }^{32}$ liquid-liquid extraction (LLE), ${ }^{33,34}$ and solid-phase extraction (SPE) ${ }^{35}$ for the extraction of the target analytes indicates that this novel method has a very short equilibrium time comparing to the mentioned methods and the extraction time needed for the proposed method is a few seconds. Quantitative results of the proposed method are better than for SPE ${ }^{35}$ and $\operatorname{LLE}^{33,34}$ methods. Relative standard deviation (RSD\%) of the proposed method is better than for SPME ${ }^{32}$ and $\mathrm{LLE}^{33}$ methods. Also, SPE and LLE methods are time-consuming and laborious, and the large amounts of organic solvents used in the extraction procedures cause problems with regards to health and the

Table 2. Determination of carbamazepine (CBZ) and lamotrigine (LTG) in human plasma and urine by IL-DLLME-HPLC-DAD

\begin{tabular}{|c|c|c|c|c|c|c|c|c|c|c|c|c|}
\hline \multirow[b]{3}{*}{ Human urine } & \multicolumn{6}{|c|}{$\begin{array}{l}\text { Spiked concentration } \\
\qquad\left(\mathrm{mg} \mathrm{L}^{-1}\right)\end{array}$} & \multicolumn{6}{|c|}{$\begin{array}{c}\text { Relative recovery }(\% \pm \mathrm{SD}) \\
n=3^{\mathrm{a}}\end{array}$} \\
\hline & \multicolumn{3}{|c|}{ CBZ } & \multicolumn{3}{|c|}{ LTG } & \multicolumn{3}{|c|}{ CBZ } & \multicolumn{3}{|c|}{ LTG } \\
\hline & 2 & 4 & 10 & 5 & 14 & 20 & $93.0 \pm 3.1$ & $103.0 \pm 1.5$ & $101.0 \pm 1.2$ & $90.0 \pm 5.0$ & $97.0 \pm 3.5$ & $99.0 \pm 4.1$ \\
\hline Human plasma & 2 & 4 & 10 & 5 & 14 & 20 & $89.0 \pm 5.4$ & $94.0 \pm 2.8$ & $96.0 \pm 2.5$ & $87.0 \pm 9.5$ & $91.0 \pm 4.5$ & $93.0 \pm 3.1$ \\
\hline
\end{tabular}

a Standard deviation

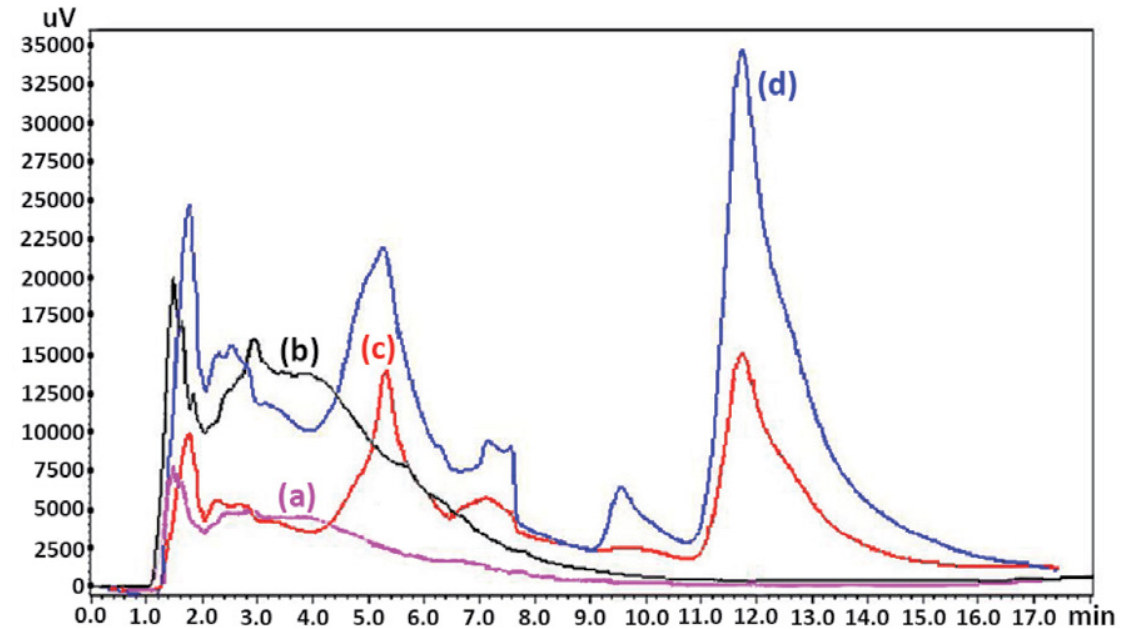

Figure 8. HPLC chromatograms, (a,b) before spiking with analytes in urine at the wavelength of 308 and $284 \mathrm{~nm}$ for lamotrigine and carbamazepine, respectively, (c) $14 \mathrm{mg} \mathrm{L}^{-1}$ (lamotrigine) and (d) $4 \mathrm{mg} \mathrm{L}^{-1}$ (carbamazepine) spiking of analytes in urine after extraction via proposed method at optimum conditions. (The retention time of LTG was $5.1 \mathrm{~min}$ and the retention time of CBZ was $12.1 \mathrm{~min}$ at the measurement in the maximum wavelengths). 


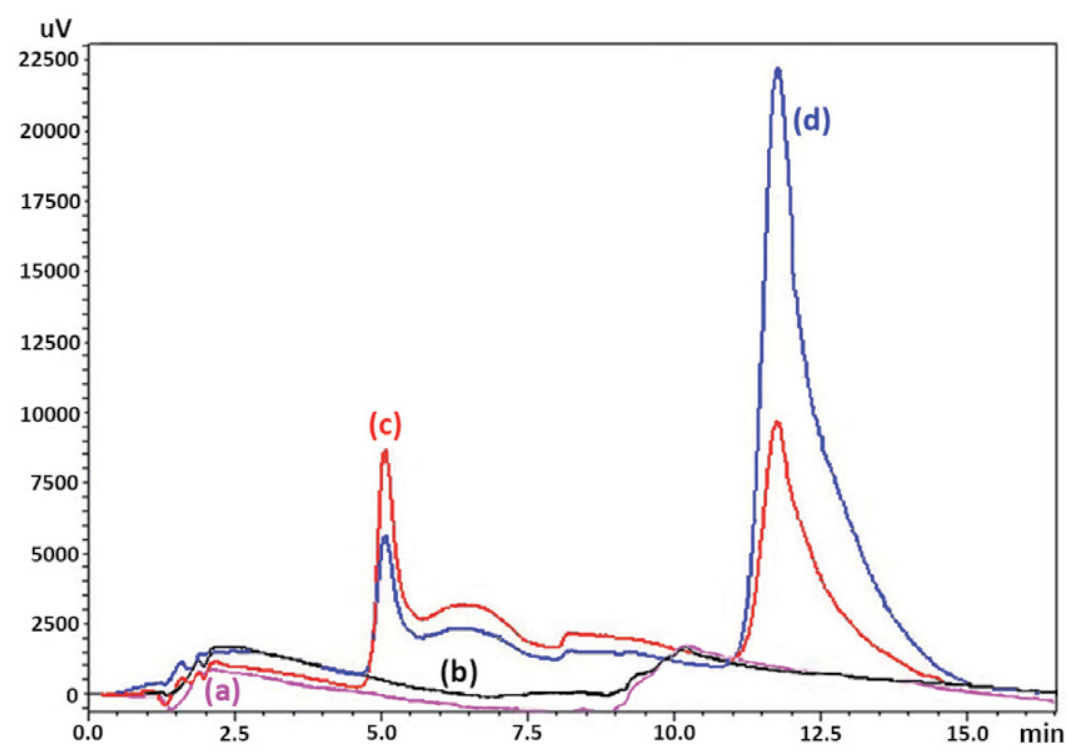

Figure 9. HPLC chromatograms, (a,b) before spiking with analytes in plasma at the wavelength of 308 and $284 \mathrm{~nm}$ for lamotrigine and carbamazepine, respectively,, (c) $14 \mathrm{mg} \mathrm{L}^{-1}$ (lamotrigine) and (d) $4 \mathrm{mg} \mathrm{L}^{-1}$ (carbamazepine) spiking of analytes in plasma after extraction via proposed method at optimum conditions. (The retention time of LTG was $5.1 \mathrm{~min}$ and the retention time of CBZ was $12.1 \mathrm{~min}$ at the measurement in the maximum wavelengths).

environment. Finally, the extraction solvent used in DLLME generally is highly toxic and not environmentally friendly. Ionic liquids (ILs) are considered to be "environmental friendly solvents". In the proposed work, in DLLME method, IL was used as extraction solvent.

\section{Conclusions}

A rapid and simple method using the ionic liquid-based dispersive liquid-liquid microextraction procedure was presented to the extract and concentrate carbamazepine and lamotrigine from biological samples.

Table 3. Comparison of the proposed method with other extraction methods for the determination of carbamazepine (CBZ) and lamotrigine (LTG)

\begin{tabular}{|c|c|c|c|c|c|c|}
\hline Methods & Sample & R.S.D.\% & $\begin{array}{c}\text { Dynamic } \\
\text { linear range } \\
\left(\mathrm{mg} \mathrm{L}^{-1}\right)\end{array}$ & $\begin{array}{c}\text { Limit of } \\
\text { detection } \\
\left(\mathrm{mg} \mathrm{L}^{-1}\right)\end{array}$ & $\begin{array}{c}\text { Extraction } \\
\text { time } \\
(\text { min })\end{array}$ & Ref. \\
\hline $\begin{array}{l}\text { SPME-GC- } \\
\text { TSD }\end{array}$ & Plasma & $<10$ & $\begin{array}{l}0.06-20 \\
\text { (CBZ); 0.2-10 } \\
\quad(\mathrm{LTG})\end{array}$ & $\begin{array}{c}0.06 \text { (CBZ); } \\
0.2 \text { (LTG) } \\
\text { (Limit of } \\
\text { quantitation) }\end{array}$ & 15 & {$[32]$} \\
\hline $\begin{array}{l}\text { Precipitation } \\
\text { and liquid } \\
\text { extraction- } \\
\text { GC-MS }\end{array}$ & Serum & $<12$ & $\begin{array}{c}0.625-20 \\
\text { (CBZ, LTG) }\end{array}$ & - & 5 & {$[33]$} \\
\hline $\begin{array}{l}\text { LLE-HPLC- } \\
\text { UV }\end{array}$ & Plasma & $<6$ & $1.0-30$ (LTG) & 0.15 (LTG) & 5 & {$[34]$} \\
\hline $\begin{array}{l}\text { SPE-HPLC- } \\
\text { DAD }\end{array}$ & Plasma & $<8$ & $0.2-25(\mathrm{CBZ})$ & $0.02(\mathrm{CBZ})$ & 1 & {$[35]$} \\
\hline \multirow{3}{*}{$\begin{array}{l}\text { IL-DLLME- } \\
\text { HPLC-DAD }\end{array}$} & \multirow{3}{*}{$\begin{array}{l}\text { Urine and } \\
\text { plasma }\end{array}$} & $\begin{array}{l}\text { Urine }(1.7 \\
\text { (CBZ), } 5.6 \\
\text { (LTG) }\end{array}$ & $\begin{array}{c}\text { Urine }(0.07-20 \\
\text { (CBZ), } 0.17-40 \\
\text { (LTG) }\end{array}$ & $\begin{array}{c}\text { Urine }(0.02 \\
\text { (CBZ), } 0.05 \\
\text { (LTG) }\end{array}$ & \multirow{3}{*}{ A few seconds } & \multirow{3}{*}{ This work } \\
\hline & & & & & & \\
\hline & & $\begin{array}{c}\text { Plasma (3.2) } \\
\text { (CBZ), 8.4 } \\
\text { (LTG) }\end{array}$ & $\begin{array}{c}\text { Plasma }(0.1-20 \\
\text { CBZ), 0.3-40 } \\
\text { (LTG) }\end{array}$ & $\begin{array}{c}\text { Plasma }(0.04) \\
\text { (CBZ), } 0.07 \\
\text { (LTG) }\end{array}$ & & \\
\hline
\end{tabular}


The proposed microextraction method is environmentally friendly (highly toxic chlorinated solvents are not required), rapid, and with a simple set-up. The proposed method has satisfying LODs which were in the range of $0.02-0.07 \mathrm{mg} \mathrm{L}^{-1}$, and precisions were in the range of $1.7-8.4 \%$. The proposed method was also applied for the analysis of drugs in urine and plasma samples and the recoveries from spiked samples were in the range of 87$103 \%$. All these results indicated that the proposed method had advantages such as good sensitivity, simplicity, easyness to operate, limited chance of exposure to the toxic solvents, and high enrichment factor. This study provides a new perspective regarding the replacement of chlorinated solvents with less-toxic solvents in DLLME and supports the use of green analytical chemistry methods. In the final experiment, the developed method was applied to the determination of carbamazepine and lamotrigine in biological samples and the acceptable results can be achieved.

\section{Acknowledgements}

Financial support by Lahijan Branch, Islamic Azad University (Lahijan, Iran) during the period of this research is gratefully acknowledged.

\section{Compliance with Ethical Standards}

Funding There is no funding for this study.

Conflict of Interest No conflict exists; author Ameneh Porgham Daryasari declares that she has no conflict of interest. Author Salumeh Ranjbar declares that she has no conflict of interest. Author Mojtaba Soleimani declares that he has no conflict of interest.

Ethical approval This article does not comprise of any studies with human participants or animals performed by any of the authors.

Informed consent No humans are involved in this study.

\section{References}

1. H. M. Neels, A. C. Sierens, K. Naelaerts, S.L. Scharpe, G. M. Hatfield, W. E. Lambert, Clin. Chem. Lab. Med. 2004, 42, 1228-1255. DOI:10.1515/CCLM.2004.245

2. A. Fortuna, J. Sousa, G. Alves, A. Falcao, P. Soares-da-Silva, Anal. Bioanal. Chem. 2010, 397, 1605-1615.

DOI:10.1007/s00216-010-3673-0

3. A. G. Gilman, J. G. Hardman, L. E. Limbird, Goodman and Gilman's the Pharmacological Basis of Therapeutics, 10th edn (McGraw Hill, New York, USA), 539, 2001.

4. S. C. Sweetman, Martindale, The Complete Drug Reference, 34th edn (Pharmaceutical Press, London), 363, 2005.

5. M. Silanpaa, L. Haataja, T. Tomson, S. I. Johannessen, Carbamazepine, in: S. Shorvon, E. Perucca, J. Engel (Eds), The treatment of epilepsy, third ed. Blackwell Publishing LTD., Oxford, 2009, pp. 459-474.

DOI:10.1007/s00216-010-3673-0

6. M. Sigrid, F. Ricardo, V. Mario, D. Marta, C. Godoy, JPC-J. Planar Chromat. 2011, 24, 222-226.

DOI:10.1556/JPC.24.2011.3.9

7. N. Jebabli, E. Gaies, H. Jebari, R. Charfi, M. Lakhal, A. Klouz, S. Trabelsi, I. Salouage, Tunis Med. 2015, 93, 565-568. 8. N. F. Youssef, E. A. Taha, Chem. Pharm. Bull. 2007, 55, 541-545. DOI: $10.1248 / \mathrm{cpb} .55 .541$

9. P. Nikolaou, I. Papoutsis, A. Dona, C. Spiliopoulou, S. Athanaselis, J. Pharm. Biomed. Anal. 2015, 102, 25-32. DOI:10.1016/j.jpba.2014.08.034

10. G. S. Elizabeth, S. Giannoutsos, D. R. Lower, M. A. Virji, M. D. Krasowski, J. Chromatogr. Sci. 2007, 45, 616-622. DOI:10.1093/chromsci/45.9.616

11. R. Theurillat, M. Kuhn, W. Thormann, J. Chromatogr. A 2002, 979, 353-368. DOI:10.1016/S0021-9673(02)01257-8

12. P. E. Morgan, D. S. Fisher, R. Evers, R. J. Flanagan, Biomed. Chromatogr. 2011, 25, 775-778. DOI:10.1002/bmc.1515

13. S. Ghatol, V. Vithlani, S. Gurule, A. Khuroo, T. Monif, P. Partani, J. Pharm. Anal. 2013, 3, 75-83. DOI:10.1016/j.jpha.2012.09.001

14. C. Linder, A. Hansson, S. Sadek, L. L. Gustafsson, A. Pohanka, J. Chromatogr. B 2018, 1072, 116-122. DOI:10.1016/j.jchromb.2017.11.005

15. J. M. Juenke, K. A. Miller, M. A. Ford, G. A. Mcmillin, K. L. Johnson-Davis, Clin. Chim. Acta 2011, 412, 1879-1882. DOI:10.1016/j.cca.2011.06.009

16. L. A. Romanlyshyn, J. K. Wichmann, N. Kucharczyk, R. C. Shumaker, D. Ward, R. D. Sofia, Ther. Drug Monit. 1994, 16, 90-99. DOI:10.1097/00007691-199402000-00015

17. K. He, T. Yonetani, Y. Asada, S. Echigo, S. Itoh, Mirochem. J. 2019, 145, 1191-1198. DOI:10.1097/00007691-199402000-00015

18. A. Klancar, M. Zakotnik, R. Roskar, J. Trontelj, Anal. Methods 2017, 9, 5310-5321. DOI:10.1039/C7AY01310H

19. M. D. Cantu, D. R. Toso, C. A. Lacerda, F. M. Lancas, E. Carrilho, M. E. Queiroz, Anal. Bioanal. Chem. 2006, 386, 256-263. DOI:10.1007/s00216-006-0629-5

20. S. Bompadre, A. Tagliabracci, M. Battino, R. Giorgetti, J. Chromatogr. B Analyt. Technol. Biomed. Life Sci. 2008, 863, 177-180. DOI:10.1016/j.jchromb.2007.12.020

21. W. Lee, J. H. Kim, H. S. Kim, O. H. Kwon, B. I. Lee, K. Heo, Neurol. Sci. 2010, 31, 717-720. DOI:10.1007/s10072-010-0257-x

22. N. R. Barbosa, A. F. Midio, J. Chromatogr. B Biomed. Sci. Appl. 2000, 741, 289-293. DOI:10.1016/S0378-4347(00)00102-X

23. A. Ferreira, M. Rodrigues, P. Oliveira, J. Francisco, A. Fortuna, L. Rosado, P. Rosado, A. Falcao, G. Alves, J. Chromatogr. B Analyt. Technol. Biomed. Life Sci. 2014, 971, 20-29.

DOI:10.1016/j.jchromb.2014.09.010

24. M. Rezaee, Y. Assadi, M. R. M. Hosseini, E. Aghaee, F. Ahmadi, S. Berijani, J. Chromatogr. A 2006, 1116, 1-9. DOI:10.1016/j.chroma.2006.03.007

25. R. Rahnama, Z. C. Jojadeh, M. R. Jamali, Acta Chim. Slov. 2012, 59, 641-647. 
26. M. R. Hadjmohammadi, S. S. Ghoreishi, Acta Chim. Slov. 2011, 58, 765-771.

27. S. Shariati, M. Golshekan, Acta Chim. Slov. 2011, 58, 311-317.

28. P. Anastas, N. Eghbali, Chem. Soc. Rev. 2010, 39, 301-312. DOI:10.1039/B918763B

29. S. Xiulan, Z. Li, Y. Fang, P. Chen, G. Ren, H. Shan, Curr. Anal. Chem. 2010, 6, 249-259.

DOI:10.2174/157341110791516954

30. J. F. Liu, J. A. Jọnsson, G. B. Jiang, Trends Anal. Chem. 2005, 24, 20-27. DOI:10.1016/j.trac.2004.09.005

DOI: $10.1016 /$ j.trac.2004.09.005
31. R. Rahnama, N. Mansoursamaei, M. R. Jamali, Acta Chim. Slov. 2014, 61, 191-196.

32. M. E. C. Queiroz, S. M. Silva, D. Carvalho, J. Chromatogr. Sci. 2002, 40, 219-223. DOI:10.1093/chromsci/40.4.219

33. J. Hallbach, H. Vogel, W. G. Guder, Eur. J. Clin. Chem. Clin. Biochem. 1997, 35, 755-759. DOI:10.1515/cclm.1997.35.10.755

34. E. Greiner-Sosanko, S. Giannoutsos, D. R. Lower, M. A. Virji, M. D. Krasowski, J. Chromatogr. Sci. 2007, 45, 616-622. DOI:10.1093/chromsci/45.9.616

35. P. Dzodic, L. Zivanovic, A. Protic, I. Ivanovic, R. Velickovic-Radovanovic, M. Spasic, S. Lukic, J. Serb. Chem. Soc. 2012, 77, 1423-1436. DOI:10.2298/JSC120106084D

\section{Povzetek}

Članek opisuje nov pristop za določanje karbamazepina in lamotrigina $\mathrm{v}$ bioloških vzorcih $\mathrm{z}$ disperzivno mikroekstrakcijo $s$ topili ob uporabi ionskih tekočin ter v nadaljevanju s tekočinsko kromatografijo visoke ločljivosti z ultravijolično detekcijo. Raziskali smo učinek različnih ionskih tekočin (IL) na učinkovitost ekstrakcije karbamazepina in lamotrigina. Najvišjo učinkovitost ekstrakcije karbamazepina in lamotrigina smo dobili z uporabo $30 \mu \mathrm{L}$ 1-metil-3-oktilimidazolijevega heksafluorofosfata [C8MIM][PF6]. Optimizirali smo še več drugih faktorjev, ki vplivajo na učinkovitost mikroekstrakcije, kot so vrsta in volumen ekstrakcijskega topila, vrsta in volumen disperzijskega topila, koncentracija soli in $\mathrm{pH}$ vzorca. Kalibracijske krivulje so bile za plazemske vzorce linearne v območju $0,1-20 \mathrm{mg} \mathrm{L}^{-1}$ za karbamazepin in $0,3-40 \mathrm{mg} \mathrm{L}^{-1}$ za lamotrigin, meje zaznave pa so bile $0,04 \mathrm{mg} \mathrm{L}^{-1}$ za karbamazepin in $0,07 \mathrm{mg} \mathrm{L}^{-1}$ za lamotrigin. Rezultati potrjujejo primernost predstavljene metode kot dovolj občutljive za analizo tarčnih analitov v vzorcih urina in plazme. 